\title{
VERONIKA BAJT \\ The Schengen Border and the Criminalization of Migration in Slovenia
}

\begin{abstract}
Detention, expulsion and deterrence have become the predominant policy response to migration. It is reported that it is becoming increasingly difficult even to claim asylum in the EU. All states restrict border access, but immigration is criminalized most stringently in cases of asylum. Noting how many national jurisdictions are adopting ever more restrictive immigration control systems, the author discusses the recent criminalization of migration in Slovenia. The country's former internal Yugoslav boundary became the European Union's Schengen border in 2007, and what was a permeable demarcation between Slovenia and Croatia up to 1991 has now become a hard border, subject to securitization and surveillance. The author explores the policy-making surrounding the symbolic construction of Slovenia as an EU member state which has been charged with the role of Schengen border defender. She shows how this shift has become apparent in Slovenia's immigration management policies, administrative practices, and political discourse.
\end{abstract}

Veronika Bajt is a Research Fellow at the Peace Institute, Institute for Contemporary Social and Political Studies, in Ljubljana.

\section{Introduction}

Both in public policy debates and in the everyday life of ordinary people, migration today is surrounded by complex overtones. It has increasingly become associated not only with issues of integration, multiculturalism, belonging, loyalty, identity, and co-existence, but also with the fear of terrorism, 'population mixing', Islamophobia, and social conflict. Although negative attitudes towards Muslims were evident in various national contexts long before the 9/11 attacks, the events of 2001 in the United States greatly intensified mistrust of Muslims and increased their social and political marginalization. After 9/11, studies reported a statistically significant surge in antiIslamic hate crimes. ${ }^{1}$ Established and promulgated by government and media

1 Bryan D. Byers/James A. Jones, The Impact of the Terrorist Attacks of 9/11 on AntiIslamic Hate Crime, Journal of Ethnicity in Criminal Justice 5, no. 1 (2007), 43-56, DOI: 10.1300/ J222v05n01_03. All internet sources were accessed on 20 October 2019. 
institutions to justify profiling, ${ }^{2}$ and to fabricate a sense of national unity behind the so-called war on terror, the 'Islamic terrorist threat' has become a catch-phrase and ready-made excuse for Islamophobia and the persecution of Muslims. The resulting perception of Muslims-and Muslim immigrants in particular-as suspect citizens has been well documented. In Europe, anti-immigrant Islamophobia is a structural phenomenon with its own specific social roots and mechanisms of functioning. In recent years, the situation has been deteriorating for people who seek asylum, and a rise in hate speech against migrants, especially Muslims, has become evident since the 2015 'refugee crisis' in the European Union (EU). ${ }^{3}$

Many national jurisdictions have adopted increasingly restrictive immigration control systems, and governments of various orientations are becoming more and more inclined to deploy criminal justice measures to address what they call the 'immigration problem'. New and increasingly 'technical forms of governance have been taken into use to control state territories', and governmental practices 'perpetually aim at making territory calculable'. ${ }^{4}$ Border issues and crime control share a discourse of protection and security, while criminal and immigration law traditionally act as gatekeepers that define the terms of social inclusion and exclusion.

So-called pushbacks in the Western Balkans have created a growing number of human rights violations, but these do not seem to bother the EU member states' elites. For refugees and others who have the right to international protection from persecution and serious human rights violations, pushbacks obstruct their chances of gaining protection and obtaining the individual assessment of their claims which is their due. At the same time, a rising proportion of the inhabitants of European countries prefer to look away from the plight of people from Syria, Pakistan, Afghanistan, and other afflicted countries across the globe. Borders are subject to increasing securitization, surveillance, and militarization, while immigration policies are more and more based on exclusion and denial of rights. Their purpose is to get control over immigrants. Even though existing research bears hardly any evidence of an immigration-crime nexus, migration law is taking over elements of criminal law in a 'criminalization of migration' for which the legal scholar Julie Stumpf coined the term 'crimmigration' in 2006. She used this term to refer

${ }^{2}$ Louis A. Cainkar, Homeland Insecurity. The Arab American and Muslim American Experience after 9/11, New York City/NY 2009.

${ }^{3}$ Fabio Perocco, Anti-Migrant Islamophobia in Europe. Social Roots, Mechanisms and Actors, Revista Interdisciplinar da Mobilidade Humana 26, no. 53 (2018), 25-40, DOI: 10.1590/198085852503880005303.

${ }^{4}$ Anssi A. Paasi, Bounded Spaces in a 'Borderless World'. Border Studies, Power and the Anatomy of Territory, Journal of Power 2, no. 2 (2009), 213-234, 213, DOI: 10.1080/ 17540290903064275. 
to the complex nexus of immigration policy and policing that had emerged in the United States after 1980. ${ }^{5}$ '[M]igration and asylum seeking,' Kogovšek wrote, 'are increasingly perceived as phenomena that cause security concerns, and therefore have to be addressed by way of control and punishment. ${ }^{6}$ With the use of immigration and criminal law as a means of exclusion, an everexpanding group of 'outsiders' is being denied the basic privileges that are now only bestowed upon citizens. ${ }^{7}$ With their status determined at the intersection between criminal and immigration law, migrants are increasingly represented as 'symbolic assailants', and this threatens their fundamental rights. ${ }^{8}$ Many states have come to perceive immigrants as chiefly responsible for certain forms of criminal activity, and thus have instilled a general fear of immigration. Detention, expulsion, and deterrence have become a predominant policy response to migration. It is reported that it is becoming increasingly difficult even to claim asylum in the EU. ${ }^{9}$

In recent years, this has become a burning issue in Slovenia. From at least June 2018, according to reports, pushbacks have led to an increasing number of human rights violations. ${ }^{10}$ This makes the Schengen border between Slovenia and Croatia a crucial area for understanding crimmigration. This border was once an internal boundary between two republics of the former federal state of Yugoslavia, but it has been turned into a 'hard border'. Slovenia's accession to the EU in 2004 and its membership of the Schengen area since 2007 saw to that: its southern border with Croatia was transformed into an external frontier of the EU and a hard line of demarcation. The metamorphosis is shown in Table $1 .{ }^{11}$ When Croatia became an EU member state in 2013, the Schengen border with Slovenia and Hungary remained intact, while the EU's external border moved to Croatia's borderline with Bosnia-Herzegovina and Serbia.

\footnotetext{
${ }^{5}$ Juliet Stumpf, The Crimmigration Crisis. Immigrants, Crime, and Sovereign Power, American University Law Review 56, no. 2 (2006), 367-419.

${ }^{6}$ Neža Kogovšek Šalamon, Mass Migration, Crimmigration and Defiance. The Case of the Humanitarian Corridor, Southeastern Europe 41, no. 3 (2017), 251-275, 251, DOI: 10.1163/ $18763332-04103001$.

7 Stumpf, The Crimmigration Crisis.

${ }^{8}$ Jize Jiang/Edna Erez, Immigrants as Symbolic Assailants. Crimmigration and Its Discontents, International Criminal Justice Review 28, no. 1 (2018), 5-24, DOI: 10.1177/ 1057567717721299.

9 Kogovšek Šalamon, Mass Migration, Crimmigration and Defiance.

${ }^{10}$ Urša Regvar, Poročilo o ugotovitvah in opažanjih o izvajanju postopkov vračanja in spoštovanja načela nevračanja (non-refoulement), Pravno-Informacijski Center Nevladnih Organizacij, July 2018, http://pic.si/wp-content/uploads/2018/07/Poroc\%CC\%8Cilo-oizvajanju-postopkov-vrac\%CC\%8Canja-PIC.pdf.

${ }^{11}$ For a historical account of the Slovenian-Croatian border creation, see Marko Zajc, ed, Ustvarjanje slovensko-hrvaške meje, Ljubljana 2018.
} 
Table 1: The Slovenian-Croatian Border

\begin{tabular}{|l|l|l|l|}
\hline Year & $\begin{array}{l}\text { EU } \\
\text { borderline }\end{array}$ & $\begin{array}{l}\text { Schengen } \\
\text { borderline }\end{array}$ & Explanation \\
\hline $\begin{array}{l}\text { Until } \\
1991\end{array}$ & No & No & $\begin{array}{l}\text { Internal republican boundary } \\
\text { within Yugoslavia }\end{array}$ \\
\hline 1991 & No & No & $\begin{array}{l}\text { Inter-state border between two } \\
\text { sovereign states }\end{array}$ \\
\hline 2004 & Yes & No & Inter-state border and EU border \\
\hline 2007 & Yes & Yes & $\begin{array}{l}\text { Inter-state border, EU and Schengen } \\
\text { border }\end{array}$ \\
\hline 2013 & No & Yes & $\begin{array}{l}\text { Inter-state border, Schengen border; } \\
\text { EU border moves to Croatia's border } \\
\text { with Bosnia and Herzegovina and Serbia }\end{array}$ \\
\hline
\end{tabular}

Having abolished borders between themselves internally, the Schengen area states have tightened controls at their common external border. This amounts to imposing virtual exclusion on non-EU nationals: 'After removing internal barriers, Europe starts to become a super-state reinventing the "hard" border protecting states and politically associated people.'12 The Schengen rules are hence designed to ensure the security of those living or travelling in the Schengen Area, while at the same time keeping others out-especially citizens of so-called 'third countries', who accordingly become subject to the ever more stringent rules that allow or deny entry.

However, it is not the aim of this study to discuss the main policies and legal changes related to the Schengen system that have occurred over the last three years-developments such as the reintroduction of internal border checks, the establishment of a European Border and Coast Guard, and the increasing use of border fences at the common external borders. ${ }^{13}$ Rather, I am interested in the policy-making surrounding the symbolic construction of Slovenia as an EU member state transformed into a Schengen border defender. ${ }^{14} \mathrm{I}$ wish to show how this shift has become apparent in Slovenia's immigration man-

${ }^{12}$ Mircea Brie/Ioan Horga, The European Union External Border. An Epistemological Approach, Revista Română de Geografie Politică 11, no. 1 (2009), 15-31, 3.

${ }_{13}$ Cf. Sergio Carrera, The State of the Schengen Area in the Light of the 2019 European Parliament Election, RSCAS Policy Paper 2019/12, European University Institute/Robert Schuman Centre for Advanced Studies, 2019, https://cadmus.eui.eu/bitstream/handle/ 1814/61595/RSCAS\%20PP\%202019_12.pdf?sequence=1\&isAllowed=y.

${ }^{14}$ For an excellent analysis of how local media and politicians legitimized Slovenia's role as the border guard of Europe, cf. Ksenija Vidmar Horvat, The Balkan Road and the Guarding of Europe. The Refugee Crisis on the Borders of Slovenia, Dve domovini / Two Homelands, no. 45 (2017), 105-119, http://twohomelands.zrc-sazu.si/uploads/issues/1488023202_ DD_TH_45_web.pdf. 
agement policies, administrative practices, and political discourse. For this reason, the present article analyses the framing of crimmigration at the normative level of institutions, and this analysis is accompanied by an examination of how specific procedures are being implemented in practice. I combine an exploration of policies and expert opinion with an analysis of the effects the criminalization of migration has on individuals who are in the process of migrating. This is backed up by details of some migrants' own experiences of the crimmigration measures. The article concludes that migration policy and Schengen border management in Slovenia has progressively moved in the direction of increased criminalization of migration.

\section{Methodology and Outline}

This study draws on interviews conducted with major actors involved in procedures relating to the criminalization of migration: key stakeholders such as state representatives, non-governmental organisations (NGOs) and migrants. Desk analysis of policies and an interview analysis method are employed. I adopt official terminology where needed (i.e. asylum-seekers, refugees) but use the general term 'migrant' to signify the mobility of people as free agents beyond their ascribed status. The situations and experiences of migrants, it must be realized, are different: some entered Slovenia legally, some irregularly; some came with their family, some migrate alone.

Using extracts from the interviewees' own narratives, the article makes it possible to associate policy measures envisioned by state actors with their immediate effects. These effects include both the implementation of measures by public employees charged with enforcing the law (e.g. the police) and the crimmigration consequences experienced by the targets of the measuresthe migrants themselves. Empirically, my study draws on thirteen detailed semi-structured interviews conducted between November 2017 and July 2019 with major actors involved in crimmigration procedures (see Tables 2 and 3). In each case, the professional affiliations and personal data of the interviewees are only broadly described, in order to ensure their anonymity.

Highlighting the continuities of how 'outsiders' have historically been framed and governed as 'Others', this article focuses on Slovenia, and uses this exemplar as evidence of the current situation of immigration and border management in the European Union. My approach to the criminalization of migration is sociological and focuses on 'discursive crimmigration'. ${ }^{15} \mathrm{I}$ am not

\footnotetext{
${ }^{15}$ On the concept of 'discursive crimmigration', cf. Joanna Parkin, The Criminalisation of Migration in Europe. A State-of-the-Art of the Academic Literature and Research, CEPS Paper in Liberty and Security in Europe no. 61, October 2013.
} 
Table 2: Interviewees: Migrants

\begin{tabular}{|l|l|l|l|l|l|l|}
\hline $\begin{array}{l}\text { Pseudo- } \\
\text { nym }\end{array}$ & Gender & Age & $\begin{array}{l}\text { Year of } \\
\text { arrival to } \\
\text { Slovenia }\end{array}$ & $\begin{array}{l}\text { Country } \\
\text { of birth }\end{array}$ & Status & $\begin{array}{l}\text { Date of } \\
\text { interview }\end{array}$ \\
\hline Samar & female & 23 & 2016 & Syria & Refugee & 18 Dec 2017 \\
\hline Peter & male & 47 & 2010 & Jamaica & $\begin{array}{l}\text { Permanent } \\
\text { residence }\end{array}$ & 08 Jan 2018 \\
\hline Amine & male & 23 & 2015 & Algeria & $\begin{array}{l}\text { Asylum } \\
\text { seeker }\end{array}$ & 12 Jan 2018 \\
\hline Aisha & female & 33 & 2016 & Morocco & $\begin{array}{l}\text { Temporary } \\
\text { residence }\end{array}$ & 13 Feb 2018 \\
\hline Esek & male & 22 & 2017 & Eritrea & Refugee & 21 Mar 2018 \\
\hline Zahim & male & 29 & 2014 & $\begin{array}{l}\text { Afghani- } \\
\text { stan }\end{array}$ & $\begin{array}{l}\text { Asylum } \\
\text { seeker }\end{array}$ & 23 Mar 2018 \\
\hline
\end{tabular}

Table 3: Interviewees: Stakeholders

\begin{tabular}{|l|l|l|}
\hline & Sector & Date of interview \\
\hline INT1 & Civil society (NGO legal expert) & 23 November 2017 \\
\hline INT2 & Police (police officer) & 26 January 2018 \\
\hline INT3 & $\begin{array}{l}\text { Government Office for the Support and Integration } \\
\text { of Migrants (Reception and Support Division) }\end{array}$ & 16 February 2018 \\
\hline INT4 & Police (Border Division public employee) & 21 February 2018 \\
\hline INT5 & Ministry of the Interior (Asylum Centre) & 28 March 2018 \\
\hline INT6 & Ministry of the Interior (Migration Office) & 16 April 2018 \\
\hline INT7 & $\begin{array}{l}\text { Government Office for the Support and Integration } \\
\text { of Migrants (Integration Division) }\end{array}$ & 04 July 2019 \\
\hline
\end{tabular}

concerned here with scholarship that examines the issue of 'migrant criminality'; my concern is with the societal trend of constructing migrants as symbolic assailants, and consequently as 'Others' who are to be feared. Instead of merely providing an account of existing laws, policies and procedures, I seek to understand the consequences of the increased use of criminal justice measures to address the 'immigration problem' as they emerge in socio-economic exclusion and the denial of migrants' human rights.

The first section of the article discusses the change in border control and the consequences of establishing the Schengen boundary between Slovenia and Croatia in 2007. The second section gives an overview of Slovenia's priorities in terms of migration management and control, and demonstrates a shift towards the criminalization of migration. The subsequent third and fourth 
sections summarize the effects the hard border with Croatia has had in recent years on people without proper entry documents, and how in consequence deterrence of irregular migration has become a policy priority, while migration in general has come to be regarded as a security risk.

\section{Fortifying the Schengen Border}

Knowledge of the wider EU framework is essential for understanding the current state of affairs in Slovenia, as well as being the best predictor of future trends. Studies problematizing asylum and deportation policies, integration, and social and labour market policies attest to the constriction and discriminatory effects of migration policies in Slovenia. ${ }^{16}$ In 2016, the European Commission presented a reform legislation package recommending a set of changes to the Common European Asylum System. The proposed statutes underwent various negotiation stages, especially ones concerned with recasting the Dublin Regulation. Three years after the proposal was presented, the European Council failed to adopt a mandate to negotiate with its Parliament. It is therefore the EU Parliament formed in July 2019 that will have to take a decision on how to proceed with this proposal. ${ }^{17}$ The Parliament's composition will without doubt affect the future of EU border management, especially since a potential new crisis management mechanism is at stake for situations where one or more EU member states comes to face 'challenging circumstances' or 'severe crisis'. From this perspective, a (re)new(ed) legislative framework is being developed in the EU. It is therefore impossible to analyse Slovenia's crimmigration policies and practices without highlighting its role as an EU member state that borders Italy, Austria, Hungary, and Croatia. The border with Croatia is a Schengen border that Slovenia is bound to uphold and protect:

'The police strengthened control at the border with Croatia with staff redeployment, technical equipment for controlling the green border, and setting up and

\footnotetext{
${ }^{16}$ Neža Kogovšek Šalamon, Migration Law in Slovenia, Alphen aan den Rijn 2011; Jelka Zorn, 'No Border, No Nation, Stop Deportation'. Protest Against Immigration Control as Empowerment, Critical and Radical Social Work 2, no. 2 (2014), 175-192, DOI: 10.1332/ 204986014X13987001103481; Mojca Pajnik / Veronika Bajt, 'Third Country' Migrant Workers as 'Third Class Non-Citizens' in Slovenia, in: Mojca Pajnik/ Giovanna Campani, eds, Precarious Migrant Labour Across Europe, Ljubljana 2011, 97-118.

${ }^{17}$ For more information, see, for example European Commission, Migration and Home Affairs, Common European Asylum System, n. d., https://ec.europa.eu/home-affairs/whatwe-do/policies/asylum_en; European Council, Council of the European Union, Reform of EU Asylum Rules, 21 November 2018, https://www.consilium.europa.eu/en/policies/ ceas-reform/; European Parliament, Legislative Train, Towards a New Policy on Migration, Reform of the Common European Asylum System (CEAS), n. d., https://www.europarl. europa.eu/legislative-train/theme-towards-a-new-policy-on-migration/file-jd-revisionof-the-dublin-regulation.
} 
maintaining temporary technical barriers. [...] Police continue training for the implementation of border control and the fitting of police officers at border crossings with technical means. ${ }^{18}$

'In all documents, Slovenia stands for the protection of the external borders of the European Union. And no distinctions are made between the external Schengen border and the EU's external border. Slovenia always emphasizes the need to protect the borders on the external boundary of the EU.' (INT5)

The fact that Slovenia's southern border with Croatia is now a Schengen border determines its foreign policy in terms of asylum and overall migration management. Prior to 2015, the number of irregular border crossings in Slovenia was low and in decline. Perceived as a mere transit country, Slovenia was also receiving very few applications for international protection. In the summer of 2015, however, there was a sudden surge of arrivals of refugees, a situation that Slovenia had not dealt with since the early 1990s when people sought refuge from the armed conflicts following the collapse of Yugoslavia. Now in 2015, an unprecedented number of people, most of them fleeing wartorn Syria, attempted to reach Europe by way of the Balkans migratory route through Greece, Turkey, Macedonia, Serbia, and Hungary. ${ }^{19}$ Refugees started arriving in Slovenia in even greater numbers in September 2015; and by October, after Hungary had closed its borders, the passage through Slovenia was the only way they could enter Austria.

With the mass migration of autumn 2015, Slovenia found itself in a completely new situation-one in which the normative framework in place for immigration control no longer functioned. With swollen numbers of people desperately wanting to cross Slovenia on their way towards Germany from Croatia, insistence on strict implementation of existing legal rules for border control was completely inappropriate. ${ }^{20}$ Eventually, the government had no other recourse but to implement a practice that already existed in Macedonia, Serbia and Croatia-creating a humanitarian transit 'corridor'. In this way, the state allowed people to enter Slovenia and receive basic reception facilities before they continued on their path towards Austria, and they could do this

\footnotetext{
${ }^{18}$ Ministrstvo za notranje zadeve, Policija, Služba generalnega direktorja policije, Letno poročilo o delu policije za leto 2018, April 2019, 30, https://www.policija.si/images/stories/ Statistika/LetnaPorocila/PDF/LetnoPoro\%C4\%8Dilo2018.pdf.

${ }^{19}$ Cf. Armina Galijaš, Permanently in Transit. Middle Eastern Migrants and Refugees in Serbia, Südosteuropa. Journal of Politics and Society 67, no. 1 (2019), 75-109, DOI: 10.1515/ soeu-2019-0004; Barbara Beznec / Marc Speer / Marta Stojić Mitrović, Governing the Balkan Route. Macedonia, Serbia and the European Border Regime, Belgrade 2016.

${ }^{20}$ Maja Ladić/Katarina Vučko, Slovenia's Response to Increased Arrivals of Refugees. We Don't Want Them, But We Also Don't Understand Why They Don't Want to Stay, in: Neža Kogovšek Šalamon / Veronika Bajt, eds, Razor-Wired. Reflections on Migration Movements Through Slovenia in 2015, Ljubljana 2016, 15-30.
} 
even if they were without documents. ${ }^{21}$ According to official police statistics, 396,240 migrants entered Slovenia using this 'corridor' between 17 September 2015 and 7 January 2016. Almost the same number of people left Slovenia to go on to Austria and other western and northern European countries. Only a handful of individuals applied for asylum, and almost no one was successfully returned by the police. The total number of people crossing Slovenia during the 2015/2016 'refugee crisis' was 452,686. ${ }^{22}$

Yet it was only during this temporary period of exemption that the Schengen border could be crossed without proper documentation. Soon the governmental discourse turned into stressing the 'security' of local people and their property, as well as seeing to the 'protection' of national interests. ${ }^{23}$ The humanitarian aspect of the 'refugee crisis', to which the government discourse at least paid lip service in August 2015, was gone within a month. It has not returned since, and has been progressively and steadily replaced by crimmigration measures and anti-migration rhetoric by a number of prominent political figures. Alongside measures for the 'control of migration flows' and the tightening of asylum legislation, the government saw to the erection of a razorwire fence along the Slovenian-Croatian border. This action in November 2015 was the ultimate sign of a hard border approach, even though the government attempted to downplay its dangers for human and animal welfare by using euphemisms such as 'technical barriers' or 'technical obstacles'. ${ }^{24} \mathrm{~A}$ state official from the Ministry of the Interior commented on the rapid policy shift: 'First we saw something like a humanitarian approach, but then we went into state protection, so the fence was a priority.' (INT6) Based on the available data, which is scarce and hard to acquire, 216 kilometres of razor-wire and panel fence had been put up along the Slovenian-Croatian border by 2018. ${ }^{25}$ Moreover the most recent visit Slovenia's prime minister, Marjan Šarec, made to the border region in July 2019 gave him an opportunity to promise 'more police patrols' and 'more kilometres of fence' to address the 'problem of irregular border crossings. ${ }^{26}$

\footnotetext{
${ }^{21}$ For a detailed analysis see Kogovšek Šalamon, Mass Migration, Crimmigration and Defiance.

${ }^{22}$ Suzana Kos, Na meji že več kot 200 kilometrov ograje, Delo, 16 May 2018, https://www. delo.si/novice/slovenija/na-meji-ze-vec-kot-200-kilometrov-ograje-51088.html.

${ }^{23}$ Cf. Vidmar Horvat, The Balkan Road and the Guarding of Europe.

${ }^{24}$ See, for instance, Cerar: V prihodnjih dnevih tehnične ovire, tudi ograja, Žurnal24, 10 November 2015, https://www.zurnal24.si/slovenija/cerar-v-prihodnjih-dnevih-tehnicneovire-tudi-ograja-259687; and Gregor Cerar, Tehnične ovire na meji zahtevale najmanj tri živalske žrtve, RTV Slovenija, 1 December 2015, https://www.rtvslo.si/okolje/novice/tehnicneovire-na-meji-zahtevale-najmanj-tri-zivalske-zrtve/380049.

${ }^{25}$ Kos, Na meji že več kot 200 kilometrov ograje.

${ }^{26}$ Simona Fajfar, Več patrulj, več kilometrov ograje in drugi ukrepi, Delo, 9 July 2019, 2.
} 


\section{The Criminalization of Migration}

As a country of immigration Slovenia is primarily chosen for reasons of employment and family reunification. The number of work permits valid on 31 December 2018 was 148,014 for 'third country' nationals and 28,029 for those from the EU. Most of these permits were issued to citizens of what had been Yugoslav republics or autonomous provinces-Bosnia and Herzegovina, Kosovo, North Macedonia, and Croatia. Correspondingly, in 2018, 65,211 residence permits were issued to 'third country' applicants and 9,025 to EU ones. ${ }^{27}$ In comparison, therefore, asylum is a minor issue. According to data from the Government Office for the Support and Integration of Migrants, on 25 July 2019 there were 680 people with internationally recognized protected status in Slovenia, 311 asylum-seekers (most of whom were housed at the Asylum Centre), and 97 persons who were waiting to file an application. ${ }^{28}$

Statistical data from the police show that there were 1,639 irregular migrants apprehended in the territory of the Republic of Slovenia between 1 January and 31 March 2019. Citizens of Morocco, Algeria and Pakistan were the ones most frequently processed for 'unauthorized border crossings'. ${ }^{29}$ With regard to crimmigration processes, the police identified 179 violations committed by foreigners who had entered Slovenia without possessing a proper travel document or papers such as a residence permit or visa. ${ }^{30}$ These numbers indicate criminal charges that are related solely to migration. The Foreigners Act and its amendments (last changed in 2017) refer to the removal of a foreigner, seizure of a foreigner's travel document, irregular border crossing, assistance in irregular border crossing, irregular retention in the country and problems with identification. ${ }^{31}$ Irregular border crossing and assistance with irregular border crossing are also covered by the State Border Control Act, and some aggravated forms of entry come under the Penal Code and its amendments

\footnotetext{
${ }^{27}$ Ministrstvo za notranje zadeve, Statistični podatki o tujcih v Sloveniji, 2019, http:// mnz.arhiv-spletisc.gov.si/si/mnz_za_vas/tujci_v_sloveniji/statistika/. All statistical information on foreigners mentioned in the following can also be found via the Employment Service of Slovenia, https://www.ess.gov.si/trg_dela/trg_dela_v_stevilkah/zaposlovanje_ tujcev, and the Ministry of the Interior, https://www.ess.gov.si/trg_dela/trg_dela_v_ stevilkah/zaposlovanje_tujcev.

${ }^{28}$ Urad vlade za oskrbo in integracijo migrantov, Aktualni podatki. Pregled stanja nastanitev na dan 5. 7. 2019, http://uoim.arhiv-spletisc.gov.si/si/statistika/aktualni_podatki/ index.html.

${ }^{29}$ Uprava uniformirane policije, Sektor mejne policije, Ilegalne migracije na območju Republike Slovenije, April 2019, 1, https://www.policija.si/images/stories/Statistika/ MejnaProblematika/IlegalneMigracije/2019/Januar-marec_2019.pdf.

${ }^{30}$ Uprava uniformirane policije, Sektor mejne policije, Ilegalne migracije na območju Republike Slovenije, 2019, 2.

${ }^{31}$ Uradni list Republike Slovenije, Zakon o tujcih (uradno prečiščeno besedilo) (ZTuj-2UPB6), 5 January 2018, 1-53, https://www.uradni-list.si/_pdf/2018/Ur/u2018001.pdf.
} 
as well. The severity of the punishments that can be incurred was increased with the most recent changes made to the Foreigners Act in 2017. ${ }^{32}$ According to the Minister of the Interior, some of these changes were made in response to the European Commission's initiative, taken with the awareness that Slovenia would become a new 'hotspot'. ${ }^{33}$ Classification as a 'hotspot' means that all the responsible EU agencies, such as Frontex, Europol, and Eurojust, work on the ground with the authorities of frontline member states facing disproportionate migratory pressures along the EU's external borders. The idea is to help these states fulfil their obligations under EU law and identify, register, and fingerprint incoming migrants with efficiency. Faced with this task, Slovenia's authorities have described the situation since 2015 as a 'full red alert', and have adopted legal measures to safeguard Slovenia from becoming a 'hotspot' ever again: ${ }^{34}$

'In the new, 2015 constellation of rebordering of Europe, fears of being caught within the iron curtains of the new epoch were being mediated through the combined invocation of the security measures and the racialization of the border. As concerns the former, assuming the role of the guardian of both its own national territory and the European empire as a whole created an image of centrality in terms of management of the crisis. With its own push to administer the "Balkan road", this peripheral state [Slovenia] could not be ignored. ${ }^{\prime 35}$

In January 2017, mirroring measures adopted over the past few years by neighbouring Hungary and Austria, Slovenia approved a bill allowing the police to seal the border with Croatia. Under the new legislation, if there should be a new influx of migrants likely to 'threaten public order or the internal security of the Republic of Slovenia', the Slovenian authorities could reject asylum-seekers directly at the border with Croatia (which is a non-Schengen member state). ${ }^{36}$ At the time, the prime minister and minister of the interior conceded that this was an 'extreme measure' the government was having to draft lest it be needed. ${ }^{37}$ But the fear-inducing tactics were escalated in February 2017 at the EU Malta summit, where the then head of the Slovenian government, Miro Cerar, warned that a new migration route had opened across the Adriatic Sea towards Istria. He said this even though data from the Slove-

\footnotetext{
32 Uradni list Republike Slovenije, Zakon o tujcih (uradno prečiščeno besedilo) (ZTuj-2UPB6).

${ }^{33}$ Zakon o tujcih ob podpori opozicijskih SDS-a in NSi-ja sprejet s 47 glasovi, RTV Slovenija, 26 January 2017, https:/www.rtvslo.si/slovenija/zakon-o-tujcih-ob-podpori-opozicijskih-sds-a-in-nsi-ja-sprejet-s-47-glasovi/413420.

${ }^{34}$ Zakon o tujcih, RTV Slovenija.

35 Vidmar Horvat, The Balkan Road and the Guarding of Europe, 113-114.

36 Uradni List, Zakon o tujcih, člen 10a (spremenjene razmere na področju migracij), 4.

37 Zakon o tujcih, RTV Slovenija.
} 
nian and Croatian police had never confirmed the allegation. ${ }^{38}$ Similar fear-inducing tactics could again be observed during the electoral campaign in the spring of 2018, when state officials and various political actors alerted voters to an 'imminent wave' of 60,000 people supposedly approaching Slovenia anew. ${ }^{39}$ Nothing of the kind happened. After the complicated shake-up leading to a minority government following the parliamentary elections of June 2018, there was little significant change in the official discourse. In October 2019, however, the constitutional judges repealed parts of Article 10b of the Foreigners Act, which had stipulated that should there be aggravated migration conditions, restriction of entry could be permitted and migrants turned away without individual consideration of their cases. ${ }^{40}$

\section{Migration Policy Priorities}

In recent years, the whole issue of migration has been largely reduced to a question of security, and this has resulted in a progressive securitization of borders and increased overall surveillance, even a militarization of society. To establish control over migrants, nation-states have shifted their discourse to discussion of the 'management' of people, who in consequence have become depersonalized and are referred to as 'flows', 'rivers', 'waves', and 'arrivals'. Governments across the world resort to penal nationalism and emphasize the rhetoric of security in their management of what they call an 'immigration problem'. It all amounts to a ploy for maintaining the Western privileged status quo. ${ }^{41}$ Global interactions and networks are expanding, however:

'The state is still a crucial organizer of territorial spaces and creator of meaning for them, even though these spaces are becoming increasingly porous. [...] Instead of being mere neutral lines, borders are important institutions and ideological symbols that are used by various bodies and institutions in the perpetual process of reproducing territorial power. ${ }^{42}$

\footnotetext{
${ }^{38}$ Aleš Gaube, 'Trdnjava Evropa' se zapira tudi proti Libiji, Cerar pa si izmišlja nove migracijske poti na Jadranskem morju, Dnevnik, 4 February 2017, https://www.dnevnik. si/1042761889.

${ }^{39}$ Kos, Na meji že več kot 200 kilometrov ograje.

${ }^{40}$ See Ustavno sodišče razveljavilo del spornega člena zakona o tujcih, IUS-Info, 15 October 2019, https://www.iusinfo.si/medijsko-sredisce/dnevne-novice/251103; European Council on Refugees and Exiles (ECRE), Asylum Information Database (AIDA), Slovenia: Constitutional Court Annuls Provision on Suspension of Asylum Procedure, 15 October 2019, http://www.asylumineurope.org/news/15-10-2019/slovenia-constitutional-court-annulsprovision-suspension-asylum-procedure.

${ }^{41}$ Vanessa Barker, Nordic Nationalism and Penal Order. Walling the Welfare State, London 2018; Alain Badiou, The Racism of Intellectuals, Warscapes, 7 June 2012, http://www. warscapes.com/opinion/racism-intellectuals.

${ }^{42}$ Paasi, Bounded Spaces in a 'Borderless World', 213.
} 
In a time of mass migration, refugees, asylum-seekers, and undocumented migrants are habitually perceived as, at best, uninvited guests and, at worst, threatening intruders. Hospitality towards them appears to be taking altruism too far. ${ }^{43}$ All states restrict border access, but immigration is criminalized most stringently in cases of asylum. According to Catherine Dauvergne, this is because asylum-seekers have so few options. ${ }^{44}$ Hence measures to 'discourage their movement must by definition be harsher than the persecutory conditions they face at home'. Moreover, because a 'successful asylum claim defeats the sovereign aspiration of the closed border, it is always in the foreground of policy-makers' concerns ${ }^{\prime}{ }^{45}$ Immigration authorities progressively adopt new policing strategies in the 'mobilization of pre-crime-type frameworks in the intent management of potentially risky travellers' ${ }^{46}$ Studies confirm how immigration law 'has regularly been deeply wedded to the criminal law and its characteristic means of surveillance, investigation, punishment, and redress. ${ }^{\prime 7}$ It is thus important to note that what we are today witnessing in terms of a systematic exclusion of foreigners is nothing substantially new. The nation-state has developed specific institutions to regulate and control human mobility, and makes a point of differentiating between nationals and non-nationals. In line with this, specific categorizations are constructed for people on the move, who are then regarded as 'objects of criminal suspicion and/or concern'. ${ }^{48}$

In Slovenia, migration policy is centralized, since most relevant measures are implemented by the Ministry of the Interior, which is responsible for asylum and migration. In July 2017, a special Government Office for the Support and Integration of Migrants (Urad vlade za oskrbo in integracijo migrantov, UOIM) was established, taking over some of the responsibilities that had previously come under the authority of the Ministry, though the devising of policies and administrative procedures for obtaining internationally protected status remain under the Ministry's jurisdiction. The UOIM and its Integration Division-despite the broad name-is only responsible for people who already have recognized status of international (or subsidiary) protection. In

\footnotetext{
${ }^{43}$ Lucia L. Zedner, Is the Criminal Law Only for Citizens? A Problem at the Borders of Punishment, in: Katja Franko Aas/Mary F. Bosworth, eds, The Borders of Punishment. Migration, Citizenship, and Social Exclusion, Oxford 2013, 40-48, 48.

${ }_{44}$ Catharine C. Dauvergne, The Troublesome Intersections of Refugee Law and Criminal Law, in: Franko Aas / Bosworth, eds, The Borders of Punishment, 76-92.

${ }^{45}$ Dauvergne, The Troublesome Intersections of Refugee Law and Criminal Law, 77.

${ }^{46}$ Leanne Weber / Sharon Pickering, Globalization and Borders. Death at the Global Frontier, London 2013, 107.

${ }^{47}$ Darshan Vigneswaran, Making Mobility a Problem. How South African Officials Criminalize Migration, in: Franko Aas / Bosworth, eds, The Borders of Punishment, 111$127,112$.

48 Vigneswaran, Making Mobility a Problem, 111.
} 
July 2019, their number was 679. The Office is situated at the Asylum Centre, and is severely understaffed, as one of my interviewees (INT7) pointed out. A number of ministries have some further role in integration and migration management, each implementing individual procedures related to its departmental jurisdiction. Among these are the Ministry of Foreign Affairs and the Ministry of Economic Development and Technology, as well as the Ministry of Labour, Family, Social Affairs and Equal Opportunities. Local communities do not have any formal power to implement asylum and migration measures, though integration is de facto managed at the local community level and sustained by various non-governmental sector programmes, most of which are funded, at least in part, nationally or by the EU.

As an EU member state, Slovenia participates in EU migration policy-making and in the implementation of EU legislation. The Slovenian police is involved in Frontex operations and carrying out EU immigration control policies. But Slovenia's chief interest has been in its neighbouring countries, especially since the events of 2015 brought the so-called Balkan route into focus:

'The European Union was really very inefficient with its measures. The fact is that legislation was simply not adapted to the situation that we were faced with. At that moment we really saw the importance of regional cooperation. Of course, in our case regional cooperation does not only mean cooperation with EU member states but regional cooperation for us is chiefly cooperation with Balkan countries.' (INT1)

The reference here is primarily to the countries of the so-called Western Balkans, and specifically to Slovenia's post-Yugoslav neighbours Bosnia and Herzegovina, Montenegro, North Macedonia, and Serbia, as well as its immediate neighbour, Croatia. Relations with these neighbours have been a key priority in Slovenia's foreign policy: this region in the immediate vicinity is 'of strategic importance for Slovenia, because it is a natural economic and security hinterland. ${ }^{\prime 4}$ In the following, the security dimension is therefore highlighted in official public statements and corroborated by the interviews with state officials.

The migration management system comprises elements of criminalization, including sanctions for irregular border crossing, (joint) expulsions, and restriction of movement, all as charges related solely to the act of migration. According to my policy analysis and interviews, Slovenia tries not to stand out from other European countries, and mainly follows the others' lead. The interviewees observed that no specific policy goals exist and that positions shift, with priorities being changed in an ad hoc manner: 'Nobody sets any special priorities in the broader sense; it is a case of simply responding to the cur-

\footnotetext{
${ }^{49}$ Ministry of Foreign Affairs, Foreign Policy and International Law, https://www.gov.si/ teme/sosescina/.
} 
rent situation [...] There is no migration policy in Slovenia at all.' (INT6) While migration policy, if it can be said to have existed prior to 2015/2016, remained stagnant, and no major problems were identified on the part of state officials, the 'refugee crisis' changed perceptions:

'With the wave of 2015/2016, when a lot of migrants arrived, some positive developments got going, due to the fact that individual institutions began to realize, "Ah! We have refugees in Slovenia"-although refugees have been in Slovenia since 1995. This can be seen as a positive shift, because at least people started to think differently and to look for some systemic (or at least temporary) solutions and improvements. On the other hand, there has been the negative shift: the polarization of Slovenia, the criminalization of this population.' (INT6)

Turning to legal immigration, economic migration is recognized as something of a priority in Slovenia because of labour demands for a migrant workforce in certain sectors of the economy, most notably construction. As shown above, there are high numbers of work and residence permits issued every year, especially to citizens of the former Yugoslav republics. However, a proactive migration policy able to address the shrinking number in the working-age population is not a priority, despite integration being treated as a keyword: 'Integration is definitely a priority.' (INT5) Formally, Slovenia claims to be in favour of mutual solidarity among the EU member states, as demonstrated by its participation in the relocation mechanism established as a consequence of the 'migration crisis'. When the European Commission planned to redistribute refugees throughout the EU-an idea that caused a major rift inside the union-Slovenia shifted its stance from voluntary to mandatory acceptance of the refugee quota among member states..$^{50}$ Once it joined the resettlement programme, its legal commitment was to host 567 people, and 253 persons were indeed relocated to Slovenia by July 2018, 81 from Italy and 172 from Greece (INT7). According to one of my interviewees, the full quota has not been achieved because of backlogs in these sending countries (INT7).

Developments at the EU level therefore run in parallel with national events. Especially during pre-election periods in member states, there is a lot of emphasis on migration policy and refugees, as well as debate on integration. There is also a tendency to split the migrant population into those seen as deserving protection ('real refugees') and those who allegedly do not. The latter ('economic migrants') may be branded as cheats. ${ }^{51}$ The shift in the debate on migration has been observed in all of Slovenia's neighbouring countries, raising its head at times of electoral campaigns. While the Slovenian media paid full attention to the fugitives arriving during the first two months of the

\footnotetext{
${ }^{50}$ Kogovšek Šalamon / Bajt, eds, Razor-Wired.

${ }_{51}$ N’Toko, Ekonomski migranti, raus! Mladina, 25 September 2015, https://www.mladina. si/169620/ekonomski-migranti-raus/.
} 
2015 'refugee crisis', migration issues started to disappear from the news and public discourse, only to reappear in the parliamentary electoral campaign held in the spring of $2018 .^{52}$ Migrations were also one of the central themes during the next spring when the European elections took place. Though the 2017 amendment to the International Protection Act in Slovenia was primarily a matter of adapting to the European acquis and not conditioned or encouraged by national policies, 'certain solutions' applied then 'may have been the result of the political environment at that time' (INT5). In fact, political discourse and the media have both played a crucial role in representing migrants as a threat in the public imagination:

'The Slovenian political strategy, which mainly focused on the implementation of successful securitization measures, was entirely in line with the Slovenian mainstream media constructions of refugees as a security, economic and cultural threat that needs to be controlled. ${ }^{53}$

\section{Hard Border vs the Right to International Protection}

An analysis of existing policies shows that, in theory, an individual has the right to access the asylum procedure and claim protection in all EU member states. However, the definition of a refugee has become too narrow to include all groups that seek refuge from threatening circumstances or wish to escape from economic exploitation and despair. The 2015 'refugee crisis' is a reflection of the present inability of both state and international law to provide protection for all those in need. All the EU member states have ratified the Geneva Convention and are bound by EU asylum and migration law, which sets forth basic guarantees for people seeking protection. However, in practice, access to asylum is so difficult that most people are forced to attempt access to EU territory by means of irregular entry. One could even say that legal access to EU territory has become practically impossible (unless perhaps by parachute).

The view that migrants are symbolic assailants has become a pervasive one among public servants who implement crimmigration practices as part of their job. Though aware that it is not within the police's remit to resolve asylum applications, a border police officer who had been in contact with many migrants said: 'If you permit free circulation across [borders], in a year or two or three, there would be chaos in Europe and in Slovenia. [...] After so many years we can see who is deserving and who is not entitled. There is abuse,

\footnotetext{
${ }^{52}$ Cf. Andreja Vezovnik, Introduction to the Thematic Section, Dve domovini / Two homelands 45, (2017), Thematic Section 'Slovenian Mainstream Media and their Coverage of the Migrant Situation', 99-103, http://twohomelands.zrc-sazu.si/uploads/issues/1488023202_DD_ TH_45_web.pdf.

${ }^{53}$ Vezovnik, Introduction, 100.
} 
exploitation. Asylum is being exploited.' (INT2) It is indeed not uncommon for public servants to speak of 'asylum shopping' and 'abuse of asylum', which shows how jaundiced the official stance towards migrants has become. In a recent attempt to prevent such terminology infiltrating official documents such as the Strategy of the Republic of Slovenia in the Field of Migration, ${ }^{54}$ a group of NGOs working in the field of asylum and integration wrote a public letter of objection:

'We insist that the document uses concepts and practices that can be demonstrated, measured, and precisely defined. [...] The notion of "abuse of asylum procedure" is not widely known and established in the field of migration. [...] In Slovenia [...] it is not possible to define statistical indicators that would allow monitoring. [...] To claim that an individual or a group abuses the system, it is necessary to have unambiguous and clearly measurable information on the alleged abuse [...]. Such a discourse in no way contributes to a constructive addressing of challenges, but it creates and inflames intolerance towards some people and groups in our country, and undermines the understanding of the right to asylum as the fundamental and individual human right on which the legal order of every democratic society is based..$^{55}$

The response they received was unequivocal:

"The term "abuse" also appears in the EMN [European Migration Network] dictionary in the area of migration and asylum in relation to the terms "asylum shopping" and "secondary movement". We believe that the term is correct, and both the content and terminology must remain in the strategy. ${ }^{\prime 56}$

Even more problematic for migrants who may be entitled to international protection from persecution and serious human rights violations are the so-called pushbacks, which prevent them from seeking protection and accessing their right to an individual assessment of their claims. Pushbacks are happening in various ways and engender a climate of fear and mistrust amongst people on the move. ${ }^{57}$ Brutality, intimidation and devious tactics by the authorities have been widely documented..$^{58}$ In 2018, reports about push-

\footnotetext{
${ }^{54}$ Ministrstvo za notranje zadeve, Strategija Vlade RS na področju migracij, 2019, https:// www.gov.si/assets/ministrstva/MNZ/SOJ/STR17072019.pdf.

55 The letter was addressed to the Ministry of the Interior, and was titled Poziv k opustitvi rabe pojma 'zloraba azilnih postopkov' (Call to abandon the use of the term 'Abuse of Asylum Procedures'), postmarked 5 June 2019 and signed by 12 NGOs, including Amnesty International of Slovenia and The Red Cross of Slovenia.

${ }^{56}$ Medresorska delovna skupina za migracije, Ministrstvo za notranje zadeve, communication sent by the Ministry. It went by post to the first signatory and was then circulated amongst the others via e-mail on 18 June 2019.

57 Cf. Galijaš, Permanently in Transit, 84-87.

${ }^{58}$ Cf. Reece Jones, Violent Borders. Refugees and the Right to Move, London 2017.
} 
backs in Slovenia began to appear..$^{59}$ The Human Rights Ombudsman's office noted cases where the personal circumstances of migrants quite possibly eligible for asylum were ignored or not seriously considered by the police as they apprehended irregular border-crossers. ${ }^{60}$ Human rights NGOs such as Amnesty International of Slovenia and the Legal Information Centre for NGOs (Pravno-informacijski center nevladnih organizacij, PIC) reported that, in June 2018, the Slovenian authorities restricted access to asylum and forced the return of several migrants. ${ }^{61} \mathrm{~A}$ detailed report prepared by the PIC mentions data obtained in Velika Kladuša and Bihać in Bosnia from witnesses who, although they wanted to claim asylum in Slovenia, were returned to the Croatian authorities. ${ }^{62}$ Unlike the Slovenian police, the Croatian authorities do not usually organize any formal returns to Bosnia, but simply drive the migrants to the vicinity of the border and leave them there. Reports indicate that they are then forced to cross the border, and that often their documents and mobile phones are systematically destroyed.$^{63}$ Various reports on pushbacks also mention beatings, threats, and humiliation. ${ }^{64}$ Official Slovenian police statistics confirm a change in practice from June 2018: although the number of people attempting to cross the border in an illicit manner had gone down, returns to Croatia markedly increased. ${ }^{65}$ At the same time, the number of people the police recorded as expressing an intention to apply for asylum fell continuously. ${ }^{66}$ Since the situation for refugees in Bosnia is worrisome, watchdog organizations-non-profit NGOs critically monitoring the activities of governments and other bodies-concluded that Slovenia is in breach of the non-refoulement principle. When such NGOs detect actions that go against human rights and public interest, they alert the public. ${ }^{67}$

${ }^{59}$ Amnesty International Slovenije, Vračanja in omejevanje dostopa do azila v Sloveniji, 19 July 2018, http://www.amnesty.si/prisilna-vracanja; Regvar, Poročilo o ugotovitvah in opažanjih; Boštjan Videmšek, Smrt v Kolpi, Delo, 14 July 2018, https://www.delo.si/sobotnapriloga/smrt-v-kolpi-70777.html.

${ }^{60}$ Urad varuha človekovih pravic. Policija v Črnomlju in Metliki zanemarja osebne okoliščine prebežnikov, RTV Slovenija, 22 August 2018, https://www.rtvslo.si/slovenija/ urad-varuha-clovekovih-pravic-policija-v-crnomlju-in-metliki-zanemarja-osebne-okoliscineprebeznikov/463823.

${ }^{61}$ Amnesty International, Vračanja in omejevanje dostopa do azila; Regvar, Poročilo o ugotovitvah in opažanjih.

${ }_{62}$ Regvar, Poročilo o ugotovitvah in opažanjih, 11.

${ }^{63}$ Regvar, Poročilo o ugotovitvah in opažanjih, 23.

${ }^{64}$ Cf. Galijaš, Middle Eastern Migrants and Refugees, 85.

${ }^{65}$ Uprava uniformirane policije, Sektor mejne policije, Ilegalne migracije na območju Republike Slovenije, 6 July 2018, 2-3, https://www.policija.si/images/stories/Statistika/ MejnaProblematika/IlegalneMigracije/2018/Januar-junij_2018.pdf.

${ }_{66}$ Prošenj za azil je vedno manj, Delo, 18 June 2018, https://www.delo.si/novice/svet/ prosenj-za-azil-je-vedno-manj-62356.html.

${ }^{67}$ Regvar, Poročilo o ugotovitvah in opažanjih. 
Nevertheless, nothing came of this complaint, as the officials failed to heed the NGO warnings. Indeed, on 10 June 2019, the Ministry of the Interior put out on its website the draft Strategy of the Republic of Slovenia in the Field of Migration that has already been mentioned and launched a 15-day consultation with civil society ${ }^{68}$ NGOs and researchers active in the field of migration and asylum presented their views and submitted their recommendations to the interdepartmental working group under the leadership of the Ministry of the Interior. They continued to monitor the process of preparing the strategy very closely and strove to achieve improvements in the text. ${ }^{69}$ But as early as 18 July 2019, the government of the Republic of Slovenia adopted the Strategy on Migration..$^{70}$ It allotted the coordination of drafting its text to the Ministry of the Interior, and this is reflected in the content of the document. It heavily emphasizes irregular migration, security issues, border protection and asylum procedures, even though most migration in Slovenia is properly documented economic migration-migrant workers easily outnumber asylum-seekers and irregular migrants. In public appearances, academic articles, media commentaries, roundtable debates and many other outlets, civil society has been calling on the government to rethink the purpose of its strategy and its overall vision of migration management, suggesting that it should treat different aspects of migration in a proportionate manner and place greater emphasis on migrant integration. Considering the crimmigration measures already in place, however, and the general direction that migration policy has been taking, it does not look as if attitudes will soften much. The current administrative and political discourse in Slovenia clearly indicates a continued shift towards security and deterrence. Moreover, apart from being a paradigmatic hard border, the Schengen boundary, as the delimiter between Europe and 'the Other', plays a much broader symbolic role, one that goes beyond the issue of Middle Eastern and African refugees:

'The confusion of history, culture and geography provided a map of the region in which Slovenia moved from the place of a peripheral Member State to the role of a Schengen centre. Above all, a critical distance from the centre, paradoxically,

${ }^{68}$ The strategy is divided into six pillars: legal migration, international protection, 'illegal' migration and return, security components, integration, and international aspects of migration. Cf. Ministrstvo za notranje zadeve, Strategija vlade RS na področju migracij.

${ }^{69}$ They also addressed a new letter to the Office of the Prime Minister of the Republic of Slovenia, postmarked 3 June 2019 and signed by 20 organizations working in the field of human rights, migration and asylum, including Amnesty International of Slovenia and The Red Cross of Slovenia.

${ }^{70}$ See Republika Slovenija, Urad Vlade Republike Slovenije za oskrbo in integracijo migrantov, Strategija na področju migracij, 18 July 2019, https://www.gov.si/novice/201907-18-strategija-na-podrocju-migracij/. 
fuelled a potent fantasy by which the regional map would, yet once more in history, show Slovenia as a non-Balkan destination. ${ }^{71}$

\section{Migration as a Security Risk}

The criminalization of migrants includes 'all the discourses, facts and practices made by the police, judicial authorities but also local governments, media, and a part of the population that hold immigrants/aliens responsible for a large share of criminal offences' ${ }^{72}$ Non-nationals are overrepresented in the criminal justice systems of European states, and public perceptions increasingly link migrants with crime, but there is a conspicuous 'lack of any concrete empirical evidence substantiating a correlation between immigration figures and crime rates'. ${ }^{73}$ Research has found no links between the intensification of criminalization trends in specific national contexts and any real increase in crime rates or immigration; ${ }^{74}$ no 'correlation in the criminalization of aliens and rises in crime' can be confirmed. Yet 'periods of economic difficulty often see the fiercest proliferation of criminalization discourses and surges of xenophobia'.75

In Slovenia, the rise in xenophobia and anti-immigration hate speech has indeed been linked to the socio-economic effects of the 2008/2009 financial crisis. ${ }^{76}$ Research confirms that most immigrants integrate, but factors such as a proliferation of immigration-related criminal offences and discriminatory treatment by police (like 'ethnic profiling') artificially amplify the statistical representation of migrants and minorities in criminality figures. ${ }^{77}$ Analysis of the discursive aspect of the criminalization of migration thus facilitates understanding of the complex social and political conditions that encourage perceptions of migrants as symbolic assailants.

The manner in which sections of the media portray migrants, combining their portrayals with a political rhetoric of fear, lead on to actual crimmigration policies. The discursive dimension of the criminalization of migration therefore goes beyond the field of criminal law: it includes the way in which the rhetoric on immigration and security implants a fear/threat image or gestalt in people's minds, which come to associate migrants automatically

\footnotetext{
71 Vidmar Horvat, The Balkan Road and the Guarding of Europe, 113.

72 Salvatore Palidda, A Review of the Principal European Countries, in: Salvatore Palidda, ed, A Review of the Principal European Countries. Racial Criminalization of Migrants in $21^{\text {st }}$ Century, Farnham 2011, 23-30, 23.

${ }^{73}$ Parkin, The Criminalisation of Migration in Europe, 2.

${ }^{74}$ Palidda, A Review of the Principal European Countries.

${ }_{75}$ Parkin, The Criminalisation of Migration in Europe, 3.

${ }_{76}$ Pajnik / Bajt, 'Third Country' Migrant Workers as 'Third Class Non-citizens' in Slovenia.

${ }_{77}$ Parkin, The Criminalisation of Migration in Europe, 2.
} 
with deviance and security risk. ${ }^{78}$ Migrants are then constructed as threatening the social order, taking 'our' jobs, undermining wellbeing, and the situation is therefore held to warrant stricter immigration control regimes. ${ }^{79}$ The mass media perpetuate crimmigration in society and affect public opinion in a highly negative way. In particular, social media platforms now enable an unprecedented, fast-spreading proliferation of fake news. Prejudice and stereotyping is used to propagate the politics of fear and create a constant state of anxiety. At the same time, the public space for competent and critical assessment of migration policies is reduced. An unfortunate 'media logic' has taken over, whereby political agendas are channelled into dominant sources which ensure that the political and economic elites obtain a platform to disseminate their stances, which, more often than not, are dogmatic, populist, and nationalist, and which strive to maintain the status quo. ${ }^{80}$ In Slovenia, the mainstream media yielded to such dominant political voices and helped their rhetoric become hegemonic by 'cutting out the voices of migrants and critical sub-political figures' ${ }^{81}$ The media spectacle during the first weeks of the mass migration in 2015, for instance, was little different from any other crisis reporting. Without the subsequent alarmist media coverage, most residents of Slovenia would have had no idea refugees were even in the country, since their contact with the local population was restricted to the bare minimum. ${ }^{82}$ Ample research confirms the immense importance of analysing the media treatment of migration-how the media report on it, how they select sources, who speaks in the media and why, and what editorial policy is in force concerning migration issues. Further, what is the impact of the media on public opinion? And how, as an upshot, does this affect the drafting of legal provisions? ${ }^{83}$

Although the state authorities refer to current migration policy trends as ones that increase the rights of asylum-seekers and other migrants, because, they say, more emphasis is being placed on integration measures, members of civil society, migration researchers, and public servants with actual field experience believe differently. They oppose this view, pointing out many areas of tightened control and disregard for migrant rights. Most of my interview-

\footnotetext{
${ }^{78}$ Marcello Maneri, Media Discourse on Immigration. Control Practices and the Language We Live, in: Palidda, ed, A Review of the Principal European Countries, 77-94.

${ }^{79}$ Doris Marie Provine/Roxanne Lynn Doty, The Criminalization of Immigrants as a Racial Project, Journal of Contemporary Criminal Justice 27, no. 3 (2011), 261-277, Thematic Section 'Slovenian Mainstream Media and their Coverage of the Migrant Situation', DOI: 10.1177/1043986211412559.

${ }^{80}$ Mojca Pajnik, Medijsko-politični paralelizem. Legitimizacija migracijske politike na primeru komentarja v časopisu 'Delo', Dve domovini / Two Homelands, no. 45 (2017), 169-184, http://twohomelands.zrc-sazu.si/uploads/issues/1488023202_DD_TH_45_web.pdf.

${ }^{81}$ Vezovnik, Introduction to the Thematic Section, 102.

82 Kogovšek Šalamon / Bajt, eds, Razor-Wired.

${ }^{83}$ Maneri, Media Discourse on Immigration; Pajnik, Medijsko-politični paralelizem.
} 
ees believed that migration and asylum policy in Slovenia is becoming more stringent:

'Generally I could say yes, yes, it is getting stricter, and of course politicians always use it for their own purposes.' (INT6)

'Asylum is becoming harder to receive. There are many more checks. In Slovenia it is getting worse. They have put up a fence.' (INT2)

'Ever since the migrant crisis, it has been getting more difficult. The very act of crossing the border is harder, with the closing of the borders and with the actions of other states.' (INT2)

In June 2019, the official number of people drowned while trying to cross the Kolpa River, which marks the border between Croatia and Slovenia, was thirteen. $^{84}$

The bureaucratic obstacles experienced by migrants have also been widely documented, ${ }^{85}$ and were confirmed by my interviewees. They reported, for example, being imprisoned for having no documents (Esek from Eritrea), trouble having permits extended despite having a Schengen visa, which resulted in a woman having to live in Slovenia illegally for a period of time (Aisha from Morocco), and encountering acts of discrimination motivated by blatant prejudice (Peter from Jamaica). In fact, Esek's assessment of restriction of movement succinctly sums up what crimmigration is about-criminalizing people for the mere act of migrating:

'It was because I escaped without documents. This is the system, a really very bad system, in Europe. Immigrants, they do not do anything, you know. Like me, I did nothing, I do not sell drugs, I do not do anything [wrong]. They just put me in prison.'

\section{Conclusion}

Around the world, governments of various stripes have become increasingly quick to deploy criminal justice measures to address the 'immigration problem'. The European Union is no exception. Existing practices of migration control 'disrupt traditional frames of understanding within criminal law and criminology', as many national jurisdictions have adopted increas-

\footnotetext{
${ }^{84}$ Videmšek, Smrt v Kolpi; V reki Kolpi znov našli moško truplo, že 13. primer od lani, 24ur.com, 18 June 2019, https://www.24ur.com/novice/crna-kronika/13-truplo-v-kolpi.html.

${ }^{85}$ Mojca Pajnik/Veronika Bajt, Migrant Remittances in Times of Economic Decline. Coping with Protectionist Policies in Slovenia, Migration Letters 7, no. 2 (2010), 179-189, DOI: 10.33182/ ml.v7i21.19.
} 
ingly restrictive immigration control systems. ${ }^{86}$ State borders are subject to increased militarization, progressive securitization and ever more high-tech surveillance. The convergence of immigration and criminal law has therefore been identified as the most significant contemporary development in immigration law. 'Both [criminal and immigration law] create insiders and outsiders. Both are designed to create distinct categories of people-innocent versus guilty, admitted versus excluded or, as some say, "legal" versus "illegal". 87

The more nation-states and supranational bodies like the EU attempt to control migration, the more the gap seems to grow between the aims and actual results of national migration policies. Noting how many national jurisdictions have been adopting ever more restrictive immigration control systems, this study has discussed the recent criminalization of migration in Slovenia. Analysing the consequences of increased use of criminal justice measures to address the 'immigration problem', I have stressed how these consequences perpetuate socio-economic exclusion and the denial of migrants' human rights. I have shown how this shift has become apparent by looking at Slovenia's immigration management policies, administrative practices and political and media discourse. I have addressed the questions of whether migration policy in Slovenia has moved towards increased criminalization of migration, and to what extent these trends may be a consequence of having to implement more general EU policies. I argue that understanding the wider EU framework is essential for understanding the current state of affairs in migration policy, as well as being the best predictor for future trends.

Focusing on the Schengen border between Slovenia and Croatia as a crucial exemplar for understanding contemporary processes of crimmigration, I have highlighted the symbolic construction of Slovenia as an EU member state that has come to regard itself as a Schengen border defender, and I have examined the policy-making accompanying this shift. Transformed from an internal Yugoslav boundary to being the European Union's outer border from 2007 onward, what was a permeable demarcation between Slovenia and Croatia (until 1991) has become a hard border subject to securitization and surveillance. In autumn 2015, a razor-wire fence was set up along its course, amplifying the effect of hostile deterrence. Although there was an immediate outcry and many public protests have taken place, and have not subsided, there are civil initiatives and political actors strongly supporting the hard border approach, and calling for even stricter border controls and a full clamp-down on irregular migration.

\footnotetext{
${ }^{86}$ Katja Franko Aas, The Ordered and the Bordered Society. Migration Control, Citizenship, and the Northern Penal State, in: Franko Aas / Bosworth, eds, The Borders of Punishment, 21-39, 21.

${ }^{87}$ Stumpf, The Crimmigration Crisis, 380.
} 
This illustrates how crimmigration measures can resonate with a section of the population and also reminds us that this section only grows when insensitive media reporting and populist political discourse breed fear and insecurity. My study has shown how the political leadership, competent institutions and most media in Slovenia have adopted crimmigration on the basis of ideologemes of national security and protection of the local population. There is little sign that this will alter in the near future: migration policy and Schengen border management in Slovenia continues to head in the direction of increased criminalization of migration.

\section{Corresponding author}

Veronika Bajt Peace Institute, Metelkova 6, 1000 Ljubljana, Slovenia.

E-mail: veronika.bajt@mirovni-institut.si 